\title{
CHINA'S EXPECTED FOREIGN POLICY AND ITS WORLD IMPACT
}

\author{
Sahibzada Muhammad Usman*
}

\begin{abstract}
This article discusses the foreign policy projection and the global influence of China. In the past few decades, China has been one of the biggest forces on the planet, from being an impoverished country disconnected from the global community. It is important to understand what drives Chinese foreign policy and how strong China will be in the future. Like several leaders before him, President Xi Jinping has stepped up commitments to expand China's global footprint by economic and political means. Many policy-makers argue that China's growth is imminent. It is clear from the extension of the military, social, economic, and diplomatic networks that China wants to improve its international community role. This review would analyze China's different policies to outline its development goals. Moreover, different scenarios are discussed to assume what Chinese future foreign policy priorities could entail for regional and worldwide players.
\end{abstract}

Keywords: China, foreign affairs, economic power, the European Union, and the United States.

\section{Introduction}

China is one of the world's oldest cultures and has been a dominant global influence in the last few decades as a permanent member of the UN Security Council. Over the last few decades, China has moved from an autonomous country disconnected from the global community, one of the world's dominant forces, and to become the world's largest economy. There is a need to hold the larger picture to understand Chinese foreign policy guidelines and why and how Chinese foreign policy decision-making works to correctly understand Chinese external relations. It is not possible to

* Ph.D. in International Relations at the University of Pisa, Italy. 
understand correctly and forewarn their overall strategy or actions on a particular basis, either against Asia, Europe, or how they approach the events in Syria or Ukraine, without fully understanding the wider foreign policy complexities behind China's policy. While China is still seen as underdeveloped, Beijing continues to extend its reach so much that many view China's emergence as an imminent new hegemonic force. China called the 21 st century a 'strategic potential' that will develop into a comprehensive national force (Defense Intelligence Agency, 2019). US lawmakers and companies must analyze China's policy objectives to offset potential aggressive actions, to safeguard interests from national security to economic.

What is the future of the foreign policy priorities and their shaping forces of China? This article has two goals. The first is to analyze China's official plans to increase its global reach through military, social, technological, and diplomatic in the future. Creating these plans would allow readers to evaluate potential opportunities and risks posed to the United States about China's plans to expand its global footprint. The second aim is to propose distinct potential possibilities by using counterfactual explanations that determine how the world scenario might look in the future, considering China's strength and impact. These pictures would help identify China's aims and the impact on other world forces, such as the EU and the US.

\section{Methodology}

Using a consistent approach to capture and interpret the results. Primary as well as secondary data, was used. Data obtained from official announcements from the Foreign Office and the Head of Countries are key instruments. In addition, official statistics from the data are included-the data obtained from books, magazines, papers, and other web databases as secondary resources.

\section{Priorities for Chinese Foreign Affairs}

Chinese foreign policy is commonly articulated through numerous concepts and phrases, including the Harmonious Environment, the Peaceful Rising/Development, and the Five Principles for Peaceful Coexistence. These, in turn, provided the basis for external policy activities. However, it is important to remember that the regime's implicit yet rather important priorities are still considered when developing foreign policy. The fundamental foreign policy of China over the last 60 years is the so-called Five Peaceful Principles. They are Reciprocal regard for the territorial rights and sovereignty, Mutual non-interference in domestic relations of one another, Mutual non-aggression, Peaceful coexistence, Dignity, and mutual gain (United Nations, 2014). In practical terms, these values facilitated 
"good neighborly relations" to prevent external instability, which has a detrimental impact on China's internal frictions, and a strict understanding of internal non-interference, particularly in Xinjiang, Tibet and Taiwan. But what are China's foreign policy priorities as we look past principles? Official concepts include: 1) national unification, territorial integrity, and sovereign security; 2) domestic political stability (Jakobson, 2013); and 3) sustainable social and economic growth in China. The result of a policy concentrated on the five values of peaceful coexistence and is guided by many core interests. As Timothy (2012) quotes, the key factors behind core interests are the external threats to China's development and dangers to China's access to foreign goods and resources. There are three main interests, territorial integrity, national security, and national sovereignty, which are straight forward. However, China appears to view the three more narrowly than other nations. It clearly does not show the same interpretive versatility as many other nations, as can also be seen in Russia's understanding of national sovereignty and territorial integrity. The fourth main interest is "National Unification," a country special to China, where division is treated as temporary when waiting for a reunited China's normal situation (Oxenstierna \& Weissmann, 2015). The focus is naturally on Taiwan's "renegade province." The trust in China's reconciliation has become greater as Macao and Hong Kong are back; Taiwan alone is absent. The two last main interests concern local matters, which also drive external policy, as has already been addressed. They are 'the basic safeguard of social and economic development interests' and 'China's social and political stability.' Looking behind the main titles on main interests, the picture becomes messy because what can be known as key interests in China is contested and discussed. It was suggested, for example, that sea lanes are the key interest. If agreed, this will affect how China's naval capacities can be established and whether US naval supremacy can be accepted in East Asia. It was also suggested that the Middle East is in China's core interest, as energy from the region is important for China's long-period economic growth. As Timothy (2012) has argued, "Core Interest" is a term that Chinese leaders are likely to expand and strengthen. These motions had also been used with China's national reunification and political system specifically listed as core interests for the first time in 2011, while Chinese officials had referred to these changes in other contexts. The White Paper on Peaceful Development also was the first to refine the idea of "developmental interests," arguing that China strives to "protect" the "sustainability" of those interests rather than to simply secure its wealth (Kavalski, 2012).

China was ready to benefit from previous influential encounters and the legacy of its past. In foreign policy, China aims to enter other nations, stressing the reciprocal advantages of operating together. In this regard, China highlights its own modernization experiences as a prosperous latedeveloping nation, a potential model for other countries (Kavalski, 2012). In 
many places, especially in the non-democratic, non-liberal, and the global South countries with a colonial history, that is seen positively (Spakowski, 2009). International policy in China is rooted in internal affairs. Indeed, China's key foreign policy aim is to ensure local political stability. The ultimate aim is to ensure the longevity of the single-party government and the communist economy. The stability of national politics and the regime's longevity depends on two factors: nationalism and ongoing domestic economic development. Nationalism has replaced here liberal philosophy to legitimize repressive single-party governance since the latter has lost all of its prestige as a means of legitimizing the circumstance. There's a clear connection between nationalism and economic growth, where economic growth is acting to appease nationalist feelings rather than excessively violent nationalist policies like Taiwan or the South China Sea- without growth, China needs to elaborate on possibilities like the conquest of new South China's islands, or even initiate an attack on Taiwan islands. Nationalism is thus beneficial but risky. Without power, China risks being actively at odds with its neighbors. It will undermine economic development. Simply placed, it is a delicate act of balance.

\section{Chinese Foreign Policy under Current Leadership}

Looking at the values behind it, it is evident that the current government of Xi Jinping is seeking a more energetic foreign policy. The new foreign policy's key purpose is to bring about modernization, to create an external environment that is peaceful and benevolent, and to take steps to develop its home economy. To accomplish these goals, China aims at establishing friendly relations with other nations, both worldwide and neighboring. It involves the handling of marine and territorial disputes with neighbors. It is also critical that the decision of America to re-focus its foreign policy on Asia is counteracted. A key aspect is the safeguarding of natural assets, including but not limited to gas and oil, to fuel local production. The ultimate objective is to ensure China's stability, create new paths for rejuvenating the nation, and create favorable conditions for the Chinese people. Currently, the international policy seems not to be a top concern for Xi Jinping, as domestic pressure seems to be his primary focus. After three decades of "opening and reformation," China is approaching more challenging times in coping with urgent domestic problems, including changing social systems, slower economic growth, and socioeconomic turmoil due to Socioeconomic inequality. Thus, the road to foreign policy can be assumed to be more domestically motivated and directed than ever, whether it be to fulfill nationalistic desires, oil needs, or the requirement for economic growth (Dotson, 2014). Given the foreign policy of Xi Jinping, a variety of goals have arisen. First of all, the need to maintain a secure foreign climate, especially for America, was stressed. During his visit to 
America in 2012, President Xi Jinping suggested a new type of relations between nations in the 21st century" widely endorsed in America in terms of its vagueness. The fundamental principles are that there is no imminent big confrontation between China and America and that a conflict will be disastrous for both sides, while non-cooperation is very expensive. So, Xi promotes strategic confidence and mutual understanding, mutually beneficial cooperation, respect for each other's main interests, and enhancing cooperation in foreign affairs. In response to America's rebalancing, Xi Jinping also refers to China's improving ties with 'former friendly countries'. These methods were not always effective, but they sent the US a message about how China hopes that Asia will rebalance. China's focus on emerging and developed powers is also part of this policy. China has sought to expand its reach on the developing world by increasing its influence and presence in Africa, Latin America, South Asia, and Central Asia. They are also looking to establish their partnership with other big developing countries, including Russia, South Africa, Mexico, and India. It contains a series of new initiatives, including the so-called Belt and Road Initiative, developing a transportation corridor to the Baltic Sea, and the Silk Road to Africa and India.

\section{China as Emerging Balancer to US Hegemony}

In 2015, China published its defense policy white paper, which showed that its army's role in raising tensions in the South China Sea had increased (Tom, 2019). The English translation was published so that the text could be read quickly and freely. The Chinese said how they wanted to protect their islands in the contested Spratly still under construction. As a global leader, China must be the paramount country in Asia, representing 30\% of the world's exports. It would have to compete with India and Japan to be supreme in Asia. Even if there is no war, the center of the world will move to the Pacific - or the Indo-Pacific, as some of us like to term it. Like any other nation, China will continue to improve its military machinery by focusing on maritime modernization. It will take offensive measures on its outskirts and probably retain internal stability. By 2049, China expects to become a powerful economic power-assisted by a forceful military power capable of resisting all opposition. It is becoming evident that China gives up its low profile and is the apparent challenger to America worldwide, starting with the West Pacific. China's latest affirmation of Asia - from the Japanese Sea to the southern Chinese Sea to Gwadar and Kyaukpyu - is also an infrastructure to minimize distances to Africa along with a naval demonstration of the Chinese threat to America's dominance. China is trying to have a de-hyphenated relationship with Pakistan and India, even though in India, this de-hyphenation is less evident. The Chinese proposals for the Maritime Silk Route and Silk Road economic belt demonstrate both their 
concern that they will be surrounded and their willingness to threaten America. There is a lot of stress on land routes to Europe. Freight train links already occur for Chinese shipments between Madrid and eastern China. China has formed a cable network for Afghanistan with a similar arrangement with Tajikistan. China and Russia jointly developed major Eurasian-wide terrestrial telecommunications connections. In the end, the challenge will be the dollar, and China strives to make it one of the IMF's reserve currencies. Obviously, Washington, seen this as a concern. The renminbi (RMB) was the second most widely used currency in exchange and energy deals that overtook the euro by the end of 2013. The RMB could be in the IMF's exclusive basket of drawing rights. Perhaps Americans are now moving for a future of many currencies.

Any of Washington's analyzes show China's successes, including the stabilization of economic growth and political stability. Chinese analysts have commented that America's policy towards China tends to be characterized by an all-inclusive policy on containment using more tools to militarily, politically, and socially to counter Chinese capabilities. According to this claim, Americans worry that continued Chinese growth would make foreign relations more assertive. Moreover, if U.S./China relations slide into war, there will be no stability in Asia-Pacific. Ultimately, Chinese observers assessed that a bipolar world would arise, with China and the U.S. as two poles, rather than a multipolar world. There will be widening disparities with other countries in this bipolar environment between China and the U.S. The power of China in the South China Sea threatens the interests of U.S. stability in the Western Pacific. But the area from Aden to Malacca and the coast from East Africa to Australia are geo-strategically and economically important for both China and India. As China gains entry to West Asia and Eurasia, India remains barred by China and Pakistan from West and Central Asia (Vikram, 2015). During his Senate Confirmation Hearing, Donald Trump's candidate to become President of the Joint Chiefs of Staff advised that China would become America's biggest military competitor by the coming century. "I think Beijing is the main contender to America national security in the next 50 years," Milley explained how China closely watched U.S. military activities in the Middle East and used the lessons to develop their military. In the face of an escalating trade war between the United States and China, his statement on China's military capability, with the United States, raising the duty rate by billions of dollars in imports from China, retaliating with tariff increases U.S. commodities (Tom, 2019).

\section{China, as Asia's Ethnic Hegemon}

This segment tried to decode and clarify China's emergence and its potential path as a global international leader. Firstly, we observed how China's active participation in global environmental management and the 
UN PKMs suggest this likelihood, according to the benevolent-hegemon form. Nevertheless, they are primarily political rather than commercial practices. The type of benign hegemony would imply constructive, liberal economic and social policies. So far, China appears reluctant and unable to introduce these in the near future:

1. It refuses to expand the domestic market to its international rivals.

2. Its monetary worth and volatility are maintained quite tightly for narrow national interests.

3. It opposes the promotion of open and equal trade between all parties, regardless of their mutual level.

Certainly, China is a very rich competitor but one that has a kind of neomercantilism stance on the foreign stage, as shown by its trading activities on the global economy.

Secondly, we are witnessing Chinese policy on island development and its push to form a Russia-China Entente to neutralize a possible systemic and regional threat. Thirdly, we have seen indications of the Third potential path. It is close to what the Dutch described and practiced as global hegemony from the late sixteenth. It will be a world hegemony based exclusively on financial and economic matters without intervention from armed wars and imposes ideological and political values and standards. From the Dutch-style point of view, a Chinese hegemon will be fairly ideologically impartial without the use or threat of military actions, partially unrelated to the administration of the foreign State system, and mainly engaged in benefit maximization.

Ideologically, China can't be a soft hegemon because economically and militarily, it lacks the kind of traditional force and the legitimacy to wield the kind of global dominance needed to administer the world's state and business processes. As regards philosophies, for instance, Yan Xuetong suggests that China would have to go beyond the existing direction of "combining Marxism with traditional standards" and instead "shaping the global order by combining a few traditional Chinese standards with a selection of liberal values that can be satisfactory for most nations" (Yan, 2018). China's potential hegemonic position and overall institutional actions are difficult to describe. However, as argued in this document, the Dutchstyle hegemony is particularly instructive in this sense. Consequently, this third alternate suggestion adds to the existing debate and inventory of a possible interpretation as either a benign or probably repressive Hegemon of China's peaceful or violent rise. Supremacy in the Dutch could be China's most feasible path to continue in its global hegemonic dominance. While China has reported tremendous financial and economic growth since 1989, its people still have a lower per capita income and relatively limited buying ability than other major global forces. In this vein, China's main driver of financial and economic development is still the relatively cheap labor cost 
and its predominantly exportation-driven economy. Moreover, China's domestic economy appears to be comparatively weak in terms of buying power per capita. Therefore, it needs foreign economic and state structures that are peaceful and increasingly productive to continue to develop and flourish. Furthermore, China's incomplete and unfair capacity inventory leaves the military weak to contend effectively with America.

Furthermore, if China were to face a possible military coalition between Russia, India, Western Europe, and the United States, it will be substantially less successful. In brief, China remains militarily peaceful and commercially active based on its monetary prowess and its traditional military competitive deficit against America and its allies. Dutch-style imperialism is thus the right match for the near future of China. Thus, the study concludes that while with a high degree of confidence, it is difficult to forecast China's future direction. The Dutch-style hegemony is the likely interpretation of China's leadership and position in the global system. Nevertheless, China's hegemonic trajectory may also rely on its internal political and economic growth. Furthermore, it remains unlikely that China, without a violent war such as, Wilhelmine Germany, and Napoleonic France, would develop leadership and global domination. Instead, as mentioned above, global Dutch-style domination seems to be a possible direction. As long as China remains purely economic, politically independent, and self-interested in the next decade (Zhao, 2018).

\section{Economic Potential of China}

The scenario suggests that most determinants of development typically stick with previous patterns. One exception: the monetary authority delays the capital infusion to avert a financial collapse and sets a moderate limit on an expansion in the debt ratio. The risk of a potential financial crash cannot be eliminated. Here we presume that in the times under discussion, there will be no financial crisis. Shift paths in some other variables are also moderately modified to show our guesses about the possible developments. It is expected to be:

1. The investments and the formation of capital begin to decline steadily. The government invests in infrastructure, but the reach and affordability of appropriate investment opportunities limit such investment through the government budget. Changes in the capital stock growth rate lagged behind changes in the investment growth rate. The capital stock growth trend was 14 percent on average from 2011 to 2015, and it is projected to decline to 7.3 percent by 2030 .

2. The population's educational level continues to rise at a steady pace, but the employees' growth in the next five years will be negative. Consequently, the average growth rate of human resources stocks has 
fallen from $2.4 \%$, which was the present pace over the last five years, to $1.5 \%$ till 2030.

3. Owing to the downturn in the economy, the urbanization rate has decreased to 1.2 percentage points per annum in the last five years, and it is projected to be 0.6 percentage till 2030 .

4. The degree of business orientation is still growing, but its speed is slow. The non-state economy's industrial value-added share is projected to grow by $88 \%$ in 2030 (Xiaolu \& Yixiao, 2016).

5. The findings of previous portions of growth accounts indicate that the net growth rate of $R \& D$ investments has slowed down and hurts economic growth. But this may be a short-term occurrence. It is expected that $R \& D$ investment growth will not decline in the next few years.

6. The trade dependence ratio is projected to decline at the same rate as in recent years, even with the growth in the economy's size. Between 2014 and 2020, it decreases by 13 percent, while between 2021 and 2030, it decreases to 19 percent. In the next five years and after 2020, the proportion of international capital in overall capital falls by one percent.

7. The demand rate has marginally risen in recent years, adding favorably to economic growth. However, the current stagnation in growth and subsequent deceleration of actual wage rises suggests that the demand rate is just 0.2 percent in the next five years.

8. In the last few years, the debt ratio has risen exponentially, rising financial vulnerabilities in the economy by ten percentage points each year. We expect that monetary policy will somehow be changed, limiting the debt level to $6 \%$ percent. After 2020, it is expected to grow by three percentage points annually, to $260 \%$ by 2030 . We presume that there is no financial disaster during these years and consider only the negative effect on economic performance from a high leverage level (Xiaolu \& Yixiao, 2016).

In the disaster situation, patterns of different variables after 2015 are considered identical to scenario one, but they are not suited to monetary policy. The debt ratio grows exponentially and reaches 260 percent. After that, a global crisis erupts. The following condition is assumed to occur:

1. A major part of bank funds has been absorbed by the growing amount of non-performing loans, contributing to a general bank system repayment collapse. Debt default takes place.

2. Banks can't continue funding the global economy by pressuring businesses to focus on informal credit sources. It leads to a drastic rise in market interest rates, increases investment expenses for businesses, and leads to rising losses and companies' collapse. The chain reaction leads to a contraction in the economy. Declines in investment and global 
capital transfers out of the market. Output and job both shrink. The urbanization trend and household income development are stagnating.

3. Government revenues are affected, and huge budgetary shortfalls emerge, which change fiscal policy from expansion to contraction, further lower demand, and lead to social crisis due to public spending shortfalls.

4. Government should follow more loose monetary policies to support the economy. However, quantitative easing is less effective in fostering growth due to overcapacity and a lack of effective investment opportunities. Rather these strategies are contributing to the explosion of economic bubbles.

5. The past overinvestment has already squeezed out productive investment space; the influence of monetary and fiscal expansion is minimal. For some years, the economy will continue to decline. The fast turnaround since 2009 is not going to happen again.

6. Because of China's role in the global economy, the disaster has a major effect on the global economy. It reinforces China's export opportunities and economic growth adversely.

7. After the recession, the real economy's setback decreases overall activity as the money supply begins to rise, potentially leading to stagflation and exacerbated social unrest and war. For some time lagging, investment slowdown after the recession limits the long-term growth of capital and human capital stocks. Slows urbanization and family use was badly affected.

The recession has long-term negative effects on post-crisis economic development, which shifted the 2021-30 period's growth direction. The following appeared to be a logical mix of findings during 2020-30. The real capital stock growth rate declines to $5.8 \%$. The human capital stock's growth rate falls to $1.2 \%$. R\&D spending is delayed and does not add substantially to TFP. Urbanization is slowing and progressing by 0.5 percentage points a year. The rate of consumption is much slower, rising by $0.2 \%$ a year. In the past, rising non-performing loans in China hurt economic conditions but did not contribute to a full-blown financial crisis. However, there are many explanations for why crises may arise in the situations we are contemplating. First, the debt ratio is unprecedentedly high. Second, greater scope than today to cope with the debt crisis. The debt ratio had been declining for several straight years before the East Asian financial crisis. In comparison, there were many successful spending opportunities in infrastructure at the moment, leaving a lot to work on expansionary fiscal policies. During the GFC, fiscal and monetary stimuli are still in force, but these circumstances no longer existed. The simulation findings show that GDP increases by an average of 2.9 percent in the crisis scenario till 2020 and that there could be more than three years of inflation, or negative growth, over that time. From 
2021 to 2030, the annual GDP growth rate recovers to $4.4 \%$, a short-term rebound that will not last. The growth rate is projected to decline to about 3 percent in 2030 (Xiaolu \& Yixiao, 2016).

\section{Belt and Road Program}

The Belt and Road program was introduced in 2013 to promote economic cooperation and connectivity with neighboring countries and numerous trading allies in Europe, Africa, and Asia. President Xi said at the APEC summit in 2017 that the Belt and Road Initiative calls for a collective commitment. It is specifically oriented to foster infrastructure buildings and connectivity, improve economic policy cooperation, strengthen growth complementarity policies, and facilitate integrated development to achieve shared prosperity (Xinhua, 2017). This initiative comes from China, and it is worldwide. It focuses on the continents of Africa, Europe, and Asia. Many US observers see BRI differently from the way Chinese leaders portray it. For instance, Nadège Rolland claimed that BRI is widely understood as China's strategy for financing and constructing Eurasia-wide infrastructure projects. In reality, infrastructure growth is just one of five components of the BRI, including enhanced regional political coordination, financial inclusion, unimpeded trade, and exchanges between individuals. In combination, the various BRI components represent the vision of China for regional unification under its leadership. The central government has mobilized its financial, political, intellectual, and military capabilities to provide top-level designs. It is mainly designed to respond to China's most urgent strategic and economic threat and to serve its vision as the region's unquestioned leader in the next decades (Nadège, 2018). It is a fantastic tactic as such. Many facets of the BRI initiative remain unknown, including the participating nations, how much China spends on funding the initiative, and what programs will be under the BRI (Xinhuanet). For instance, the Belt and Road Portal is currently listed on its website by profiles from 70 nations. In 2017, China's official media announced that 86 nations and global organizations had signed 100 collaboration deals under the BRI with China (The Economist, 2016). Nadège Rolland stated that China had promised \$1 trillion but potentially spent $\$ 8$ trillion on BRI. This initiative could improve China's economy and its picture of soft power (World Economic Forum, 2017). China hopes to get a decent return on its currency assets, provide Chinese businesses with new investment prospects overseas, establish new markets for overcapacity industries, and promote economic growth in China's poorest regions. But if creditors do not repay loans or beneficiary nations do not deem Belt and Road to be valuable, the project will face financial risks. The US criticized certain facets of the Belt and Road initiative and stated that we looked at the practices and actions of others in the region, especially China, and the structures of funding it gives to so 
many of those nations that it induces massive debt levels to saddle them. They also do not build employment, which infrastructure projects can create enormous jobs in those economies, but they all too often welcome foreign workers to undertake these infrastructure projects. Funding is designed in such a fashion as to make potential financing very difficult to accomplish and also has very subtle financial causes, resulting in default financing and a transfer of debt to justice (U.S. Department of State, 2017). China has since taken other big financial steps. In 2014, China announced a $\$ 100$ billion International Development Bank in Shanghai, alongside South Africa, India, Russia, and Brazil. The new bank is expected to support development programs in developed nations.

\section{Conclusion}

Over the last decade and a half, there have been significant Chinese foreign policy changes, with Xi Jinping's more aggressive external policy as just the latest example. China will not become a status quo force that embraces the environment under Xi Jinping, nor are we expecting China to become a revisionist power to modernize the global order. Even if we agree that Xi leans to "fight for achievements," as the data so far suggests, it still is doubtful that the old Chinese foreign policy tactic of "holds a low profile" would be fully deviated. In the simple scenario, economic growth tends to stall as a natural continuation of past developments, and between 2010 and 2020, the government's goal of doubling GDP is not achieved. In 2030, the GDP per capita is roughly US\$15,900, making it unlikely that China will be a nation with high incomes at that time. When monetary policy is not changed, and the debt level begins to escalate exponentially, this crisis occurs. In that situation, a financial recession is expected to take place, pushing the economy for years to stagnate, with long-term negative consequences. By 2030, China is not a nation with high incomes and has been stuck in middle-income conditions. By practice and policy, China aspires to expand its foreign impact by military, social, economic, and political means. With its role as a permanent member of the UN Security Council and its position as the world's second-largest economy, China has the means to control global and regional players in the future. But China also faces foreign and domestic obstacles that it must resolve to potentially threaten America. Despite these aspirations, China must contend with its increasing salary disparity and domestic uncertainty about its minority groups. Moreover, it takes years for China to build a sophisticated army to counter America and establish an autonomous domestic economy completely operating. America expands its leverage using military, social, economic, and political networks to ensure its presence in regions where China might impose pressure to brace enforcing policies. While many 
speculations are made regarding the balance of forces in the future, it is obvious that China is a particular danger to be watched by America.

\section{References}

Defense Intelligence Agency. (2019). "China Military Power: Modernizing a Force to Fight and Win." http://www.dia.mil/Portals/27/Documents/News/Military/Power/Publica tions/China_Military_Power_FINAL_5MB_20190103.pdf.

Dotson. (2014). "Political Factions and Spicy Ginger: Elder Networks in PRC Politics (Part 1).” China Brief. 14(19): 14-19.

Jakobson. (2013). "China's Foreign Policy Dilemma." Lowy Institute for International Policy. http://www.lowyinstitute.org/publications/chinasforeign-policy-dilemma

Kavalski. (2012). The Ashgate Research Companion to Chinese Foreign Policy. Farnham: Ashgate.

Nadège, R. (2018). “China's Belt and Road Initiative: Five Years Later". https://www.uscc.gov/sites/default/files/Rolland_USCC\%20Testimony_ 16Jan2018.pdf.

Oxenstierna, and Mikael. (2015). China and Russia - A Study on Cooperation, Competition and Distrust. Stockholm: Swedish Defence Research Agency (FOI).

Spakowski. (2009). "National Aspirations on a Global Stage: Concepts of World/Global History in Contemporary China." Journal of Global History. 4(3): 475-95.

The Economist. (2016). "Our bulldozers, our rules, China's foreign policy could reshape a good part of the world economy". https://www.economist.com/news/china/21701505-chinas-foreign-

policy-couldreshape-good-part-world-economy-our-bulldozers-our-rules

Timothy. (2012). "What Does China Want? Discerning the PRC's National Strategy." Asian Security. 8(1): 54-72.

Tom, P. (2019). "Trump's pick to lead the armed forces says China will be the US's biggest military threat for 100 years and warns it is improving very, very rapidly", Business Insider. https://www.businessinsider.com/china-main-us-challenger-over-nextcentury-says-military-chief-2019-7?IR=T

U.S. Department of State. (2017). Remarks on "Defining Our Relationship with India for the Next Century". https://www.state.gov/secretary/remarks/2017/10/274913.htm.

United Nations. (2014). "Agreement between the Republic of India and the People's Republic of China on trade and intercourse between Tibet region of China and India." https://treaties.un.org/doc/publication/unts/volume\%20299/v299.pdf 
Vikram, S. (2015). "How China is emerging as an obvious challenger to US globally", The Economic Times. https://economictimes.indiatimes.com/blogs/et-commentary/how-chinais-emerging-as-an-obvious-challenger-to-us-globally/

World Economic Forum. (2017). "China's \$900 billion New Silk Road. What you need to know". https://www.weforum.org/agenda/2017/06/china-new-silk-roadexplainer/.

Xiaolu, W. and Yixiao, Z. (2016). "Forecasting China's Economic Growth by 2020 and 2030", The Australian National University, Canberra, Australia.

Xinhua. (2017). "Full text of Xi Jinping's report at 19th CPC National Congress". http://news.xinhuanet.com/english/special/201711/03/c_136725942.htm.

Xinhuanet. "China signs cooperation agreements with 86 entities under Belt and Road". http://www.xinhuanet.com/english/201712/23/c_136846221.htm.

Yan, X. (2018). Chinese values vs. liberalism: What ideology will shape the international normative order? Chinese Journal of International Politics, 11(1), 1-22.

Zhao, S. (2018). A revisionist stakeholder: China and the post-World War II world order. Journal of Contemporary China, 27(113), 643-658. 